\title{
Oxygen Transport Membranes and their Role in CO2 Capture and Syngas Production
}

Muhammad Riaz* and Muhammad Abdullah Butt

Department of Chemical Engineering, School of Chemical and Materials Engineering, National University of Science and Technology, Islamabad, Pakistan

\begin{abstract}
Membrane technology for gas separation has seen remarkable improvements in the last 20 years, particularly in the area of air separation for a cost-effective production of highly pure oxygen gas. It is rapidly paving way for alternate route to orthodox separation processes like cryogenic distillation. Solid-state electrochemical cells based on oxygen-ion conduction permit high temperature selective transport of $\mathrm{O}_{2}$ in the form of ionic flux. Hence these systems can act as filters for molecular oxygen either for generation or separation of oxygen gas. The solar thermochemical conversion of $\mathrm{CO}_{2}$ and $\mathrm{H}_{2} \mathrm{O}$ into syngas is usually carried out at a high temperature of above $1500^{\circ} \mathrm{C}$ in repeated heating-cooling cycles with the help of durable metal oxide catalysts. Oxygen Transport Membranes (OTMs) are high density ceramic membranes which display mixed conductivity of oxygen ions and electrons and a two-phase mixed metal oxide OTM could thermo-chemically convert $\mathrm{CO}_{2}$ and $\mathrm{H}_{2} \mathrm{O}$ to syngas in a single step with an $\mathrm{H}_{2} / \mathrm{CO}$ ratio of 2:1; thus offering an alternative route for syngas production. OTMs also propose a favourable technology for oxy-fuel and $\mathrm{CO}_{2}$ capture processes for gas and coal based power plants. Latest progresses in the field of ceramic membrane for oxygen separation from air at high temperatures vis-à-vis numerous materials and the prospect of ceramic-based membranes for the same are reviewed
\end{abstract}

Keywords: Synthesis gas; $\mathrm{H}_{2} \mathrm{O}$ splitting; $\mathrm{CO}_{2}$ decomposition; $\mathrm{CO}_{2}$ capture; High temperature ceramic membranes

Abbreviations: OTM: Oxygen Transport Membrane; MIEC: Mixed Ionic Electronic Conducting; ASU: Air Separation Unit

\section{Introduction}

Oxygen is one of the most widely used chemical, ranked among the top five being produced in the world [1]. $\mathrm{O}_{2}$ separation from the air is quite a large industry, with more than 100 million tons per year of production capability [2]. This market is expected to expand considerably due to the necessity of $\mathrm{O}_{2}$ as feedstock for all sizable clean energy technologies [3]. Oxy-fuel combustion process and oxygen-blown gasification for conversion of natural gas and coal to syngas for subsequent electricity generation, and production of transportation fuels and other chemicals are but a few examples of such technologies [4].

Cryogenic and non-cryogenic distillations are the two orthodox technologies frequently used for the air separation. The second involves air separation at atmospheric temperatures using adsorbents based on molecular sieves through either Pressure Swing Adsorption (PSA) or membrane separation process. Lately, another class of air separation has evolved built around specific ceramic membranes that can effectively separate $\mathrm{O}_{2}$ from air at higher temperatures. This new method is based on high density ceramic membranes which perform separation at temperatures between $800^{\circ} \mathrm{C}$ and $900^{\circ} \mathrm{C}$. Mixed Ionic Electronic Conducting (MIEC) membranes, Ion Transport Membranes (ITM), and Oxygen Transport Membranes (OTM) are the acronyms used for these membranes.

A solid electrolyte membrane based on an oxygen-ion or mixed oxygen-ion and electronic conducting material is permeable only to oxygen (as ionic flux) at high temperatures, but not to other gases. Therefore, these membranes can be employed for making highly pure $\mathrm{O}_{2}$, enriching $\mathrm{O}_{2}$ in atmospheric air, removing $\mathrm{O}_{2}$ from a gas stream or an enclosure, and controlling $\mathrm{O}_{2}$ in the gas stream at a preordained level. An oxygen-ion conducting ceramic membrane operating as a fuel cell can also be used for making syngas by the partial oxidation of methane [5-7]. Methanol, produced from syngas, is considered to be a multipurpose fuel for use in fuel cells for transport, portable power and remote area stationary applications. OTMs also propose a favourable technology for oxy-fuel and $\mathrm{CO}_{2}$ capture processes for gas and coal based power plants.

\section{Operating principle}

Lately, ardent research efforts have been performed for advancement of $\mathrm{O}_{2}$ separating ceramic-based membranes at hightemperature operations. These systems can be characterized as (i) pure oxygen conducting and (ii) mixed ionic-electronic conducting membranes. Pure $\mathrm{O}_{2}$ conducting membranes comprise of solid electrolytes (Figure 1 (a)) which are provided with electrodes for electron conduction. $\mathrm{O}_{2}$ can be conveyed from one side of the membrane to another for storage as pure gas with the application of a voltage across the solid electrolyte cell consisting of an ion-conducting $\left(\mathrm{O}^{2-}\right)$ electrolyte membrane coated with electrodes on both sides. These membranes are typically driven by either voltage or current and provide much better dominion over the level of $\mathrm{O}_{2}$ produced or removed from a gas stream. The $\mathrm{O}_{2}$ flux is directly related to the current flowing through the membrane and maximum attainable oxygen flux is determined by the applied voltage and electrical resistance, which ensuingly depends on the operating temperature, stability of the material, conductance of the ceramic membrane and the choice of electrode materials.

For oxygen enrichment in air, the oxygen produced can be mixed

*Corresponding author: Muhammad Riaz, Department of Chemical Engineering School of Chemical and Materials Engineering, National University of Science and Technology, Islamabad, Pakistan, E-mail: mriaz.che5@scme.nust.edu.pk

Received May 07, 2018; Accepted May 22, 2018; Published May 28, 2018

Citation: Riaz M, Butt MA (2018) Oxygen Transport Membranes and their Role in $\mathrm{CO}_{2}$ Capture and Syngas Production. J Membr Sci Technol 8: 181 doi:10.4172/2155-9589.1000181

Copyright: ( 2018 Riaz M, et al. This is an open-access article distributed under the terms of the Creative Commons Attribution License, which permits unrestricted use, distribution, and reproduction in any medium, provided the original author and source are credited. 
(a)

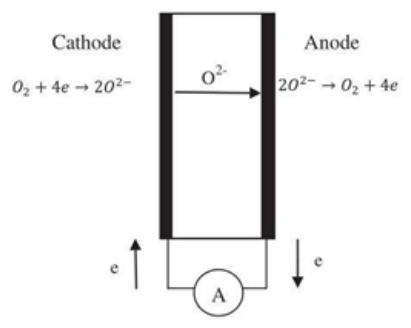

(b)

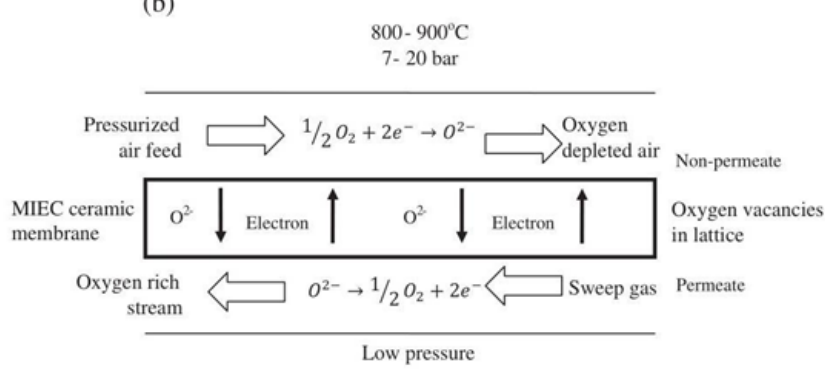

Figure 1: (a) Solid electrolyte; (b) Mixed conducting dense ceramic membranes [12].

with air to achieve desired levels. Figure 2 describes the operating principle of a membrane system for removing or controlling oxygen levels in a gas stream. In the control loop feedback mode, for accurate control of oxygen in the gas stream, a signal is sent to the microprocessor to increase or decrease the electric current flowing through the oxygen separation device by the oxygen sensor placed downstream.

Second category belongs to the membrane which is a mixed conductor e.g., a two-phase mixture of oxygen-ion and electronic conducting materials or a single-phase material with mutual oxygen-ion and electronic conducting ability. The oxygen in the air combines with the electrons in the membrane to harvest negatively charged oxygenions. No electrodes or external circuits are required for this system to function and the driving force for oxygen-ion passage is provided by the temperature and pressure differentials. The pressure difference across the membrane may be provided by either a high pressure on the air side or a lower oxygen pressure in the compartment where $\mathrm{O}_{2}$ is produced. The behaviour of electronic conductivity as an internal short circuit gives rise to the permeation of $\mathrm{O}^{2-}$ ions from higher to lower $\mathrm{O}_{2}$ partial pressure side, at the same time maintaining the overall charge neutrality by an offsetting flux of electrons (Figure 1 (b)). Such systems have promising prospects for large scale $\mathrm{O}_{2}$ generation. The differential of partial pressure across the membrane can also be provided by maintaining air on one side and natural gas on the other side of the membrane. Partial oxidation reactors, using mixed ionic/electronic conductors, are ideal for the manufacture of syngas as a feedstock for liquid fuel production. Such a system would utilize the energy produced internally to be thermally and electrically self-sustaining or for cogeneration of both syngas and electricity. The overall efficiency of these systems can be optimized by the choice of materials, the operating temperature, fabrication techniques, the engineering of the device and the overall design.

\section{Transport mechanism in OTMs}

$\mathrm{O}_{2}$ permeation through a nonporous MIEC material is restricted by bulk diffusion limitations, surface exchange resistance, or both with bulk diffusion being the controlling step in case of adequately thick membrane. Figure 3 depicts the mechanism for $\mathrm{O}_{2}$ permeation through an MIEC membrane where the permeation process is distributed into three distinct zones: (i) an interfacial zone on air or the high partial pressure side; (ii) a central bulk zone; and (iii) an interfacial zone on sweep gas or the low oxygen partial pressure side. Membrane thickness and material are the two factors on which the performance of $\mathrm{O}_{2}$ permeation flux is dependent. The permeation conditions like temperature, pressure and flow rate of sweep gas also play a vital role.

\section{Ceramic membrane materials}

Zirconia doped with different levels of $\mathrm{Y}_{2} \mathrm{O}_{3}$ possesses good oxygenion conductivity and hence is excellent material for the fabrication of ceramic membranes. Commercial powders of various compositions can easily be sintered to near theoretical density at temperatures in the 1400$1500^{\circ} \mathrm{C}$ range. These materials remain mainly oxygen-ion conductors over wider ranges of oxygen partial pressures and temperatures and are quite safe to use in a variety of applications [8]. Replacing $\mathrm{Y}_{2} \mathrm{O}_{3}$ with $\mathrm{Sc}_{2} \mathrm{O}_{3}$ has the effect of increasing the ionic conductivity. The sintered bodies of such materials can be manually handled with relative ease as the mechanical properties of most doped zirconia materials are adequate at both room temperature and at the cell operating temperatures [8] These materials can be easily fabricated into various shapes (tubes, flat plates, etc.) and sizes depending on the design of the oxygen separation device. However, there is a limit on the thickness of the material, which can be produced for self-supporting membranes. A benefit of the flat

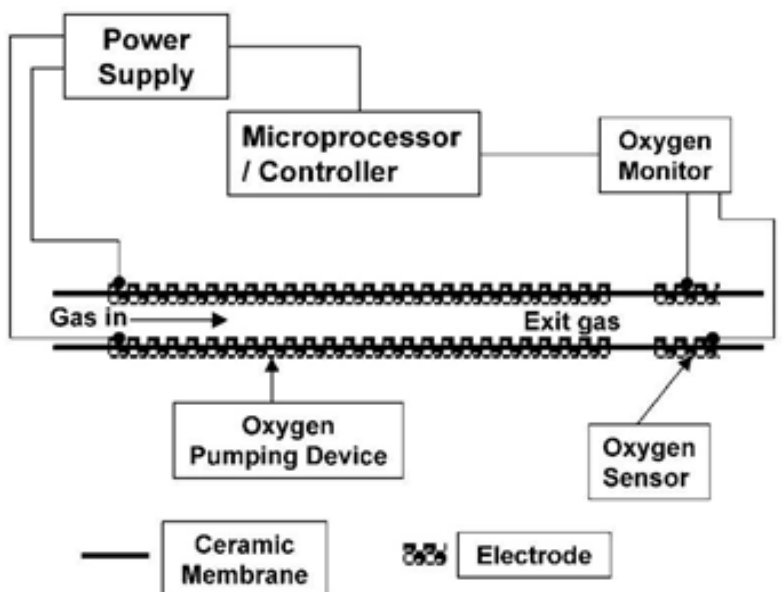

Figure 2: Oxygen separation device for $\mathrm{O}_{2}$ removal or precise control of $\mathrm{O}_{2}$ in the gas stream.

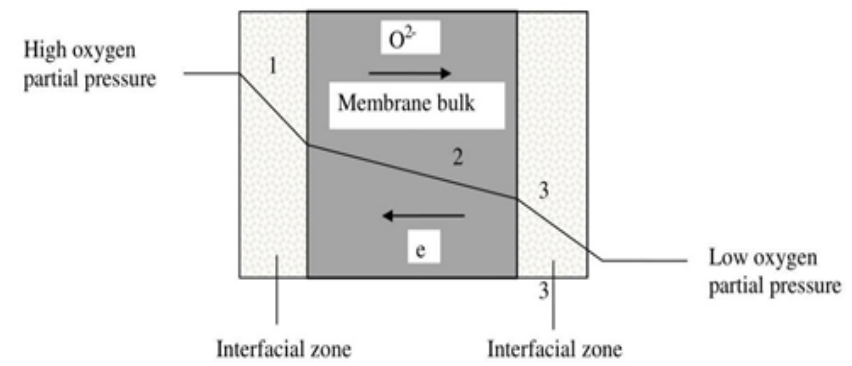

Figure 3: $\mathrm{O}_{2}$ permeation through MIEC membrane [12] 
Citation: Riaz M, Butt MA (2018) Oxygen Transport Membranes and their Role in $\mathrm{CO}_{2}$ Capture and Syngas Production. J Membr Sci Technol 8: 181. doi:10.4172/2155-9589.1000181

Page 3 of 8

plate designs is high oxygen production or removal capacity per unit volume of the membrane but they require high temperature seals and exotic materials for interconnecting various cells and thus have low thermal cycling capability. The tubular designs require minimal sealing and the thermal cycling capability is expected to be significantly higher compared with the flat plate design. With the use of zirconia-based membranes, oxygen flux density of upto $1.5 \mathrm{~cm}^{3} \mathrm{~min}^{-1} \mathrm{~cm}^{-2}$ electrode/ electrolyte contact area can be easily achieved at temperatures around $750^{\circ} \mathrm{C}$.

Materials like doped $\mathrm{CeO}_{2}$, and lanthanum gallates $\left(\mathrm{LaGaO}_{3}\right)$ are suitable for low temperature operation. In the $\mathrm{CeO}_{2}$ system, the highest ionic conductivity has been observed for $\mathrm{Sm}_{2} \mathrm{O}_{3}$ and $\mathrm{Gd}_{2} \mathrm{O}_{3}$ dopants [8]. The only problem with these materials would be their reported low mechanical strength of around $150 \mathrm{MPa}$ at room temperature, which would make the fabrication and handling of devices somewhat cumbersome [8].

Bi2O3 doped with metal oxides such as $\mathrm{Y}_{2} \mathrm{O}_{3}, \mathrm{Gd}_{2} \mathrm{O}_{3}, \mathrm{Er}_{2} \mathrm{O}_{3}, \mathrm{Dy}_{2} \mathrm{O}_{3}$, $\mathrm{Nb}_{2} \mathrm{O}_{5}, \mathrm{Ta}_{2} \mathrm{O}_{5}$, etc., becomes an oxygen-ion conductor with significantly higher conductivity than that of doped $\mathrm{ZrO}_{2}$ or $\mathrm{CeO}_{2}$ [8]. Another class of materials is from the BiMVOx family. These materials have high oxygen-ion conductivity [8] but most bismuth oxide based materials have extremely poor strength and can be easily damaged or eroded in low oxygen partial pressures and therefore are likely to have limited applications. For example, membrane devices that are constructed using these materials may be suitable for oxygen generation from air but are unlikely to be suitable for oxygen removal from low oxygen partial pressure gases. Such materials nevertheless can be fabricated into corrugated or honeycomb structures and are ideal for oxygen production in large quantities at lower operating temperatures.

Several mixed conducting materials having high oxygen-ion conductivity have been identified. Figure 4 shows the ideal structure of such materials, also known as perovskites. The most prominent materials are $\mathrm{SrC}_{\mathrm{o}} \mathrm{O}_{3-\delta}$ doped at the A-site (for e.g., with $\mathrm{La}, \mathrm{Gd}, \mathrm{Nd}, \mathrm{Sm}$, $\mathrm{Pr}$, etc.) and at the B-site (e.g., with $\mathrm{Fe}, \mathrm{Cr}$ and $\mathrm{Ti}), \mathrm{La}_{1-\mathrm{x}} \mathrm{Sr}_{\mathrm{x}}\left(\mathrm{Ga}_{1-\mathrm{y}} \mathrm{M}_{\mathrm{y}}\right)$ $(\mathrm{M}=\mathrm{Fe}, \mathrm{Co}) \mathrm{O}_{3 \pm \delta}$ and $\mathrm{Sr}_{4} \mathrm{Fe}_{6-\mathrm{x}} \mathrm{Co}_{\mathrm{x}} \mathrm{O}_{13 \pm \delta}$ [9-11]. In these materials, $\mathrm{O}_{2}$ permeation flux density relies on membrane thickness, bulk diffusion rates, temperature, gradient of $\mathrm{O}_{2}$ partial pressure across the membrane and surface $\mathrm{O}_{2}$ exchange rates. For air on one side and $\mathrm{He}$ on the other side of the membrane, $\mathrm{O}_{2}$ permeation flux density of upto $1 \mathrm{~cm}^{3} \mathrm{~min}^{-1}$ $\mathrm{cm}^{-2}$ at $900^{\circ} \mathrm{C}$ and $2.5 \mathrm{~cm}^{3} \mathrm{~min}^{-1} \mathrm{~cm}^{-2}$ at $1000^{\circ} \mathrm{C}$ has been reported [9-11].
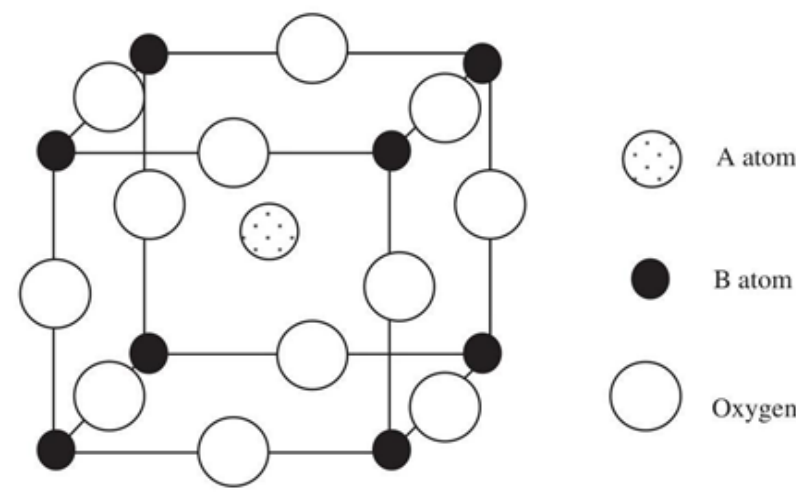

Figure 4: Ideal structure of perovskite structure $\mathrm{ABO}_{3}$ [35].

\section{Applications}

Oxygen separation has diverse applications including uses of $\mathrm{O}_{2}$ for glass making, patients with chronic lung diseases, food processing, semiconductor manufacturing industry and the metallurgical industry (e.g., copper and steel production), combustion processes where higher efficiency and lower emissions are critical as with the for hydrocarbon fuels, cutting and welding, biological water purification, the petrochemical industry for converting natural gas to liquid fuels, clean waste incineration, aeration in aquariums and fish farming-oxygenation of fish-breeding tanks. The oxygen pumping devices based on oxygen-ion conducting ceramics can also act as filters for $\mathrm{O}_{2}$, and therefore could be utilized for $\mathrm{O}_{2}$ generation in outer space, or used in hermetically sealed transport carriers, or armoured vehicles to supply oxygen, which is free of toxic substances. Such oxygen separation devices can also be used to accurately control oxygen concentrations in a gas stream (by pumping oxygen in or out) when operated in a controlled loop feedback mode. Similarly, an oxygen-ion conducting membrane system can be used to supply nitrogen from air, or for gas purification, for example, removal of oxygen from an inert gas such as argon containing substantially higher amounts of oxygen. Other uses of oxygen-ion conducting membrane reactors include production of hydrogen by electrolysis of steam, NOx reduction, and production of chemicals.

The existing orthodox oxygen separation methods can be classified into cryogenic and non-cryogenic methods. In the cryogenic separation, air is purified, cooled to liquid form followed by subsequent distillation of $\mathrm{O}_{2}$ from liquid air. Such plants are huge and expensive. On the other hand, pressure or vacuum swing adsorption methodologies are mainly employed in non-cryogenic methods for oxygen supply in which, molecular sieves are used to remove nitrogen from atmospheric air and $\mathrm{O}_{2}$ is concentrated to $95-99 \%$. The technology utilizing oxygenion conducting materials (ceramic membrane) has distinct advantages in that the physical (ceramic) barrier produces oxygen of extremely high purity by preventing any sort of contamination from entering the affluent gas stream. Moreover, similar devices can also be used for purification of gases containing oxygen, oxygen removal from gas streams and enclosures to extremely low levels and to control oxygen level in gas streams.

\section{OTMs for syngas production}

Syngas is an antecedent to liquid hydrocarbon fuels like methanol which is used in electrolyte membrane fuel cells. Syngas also serves as a rudimentary chemical for a huge number of applications in metallurgical and petrochemical industries and it also be used as a fuel to generate electricity. The orthodox processes for converting natural gas to syngas are based on partial oxidation or steam reforming or both. The main cost related partial oxidation is that of the $\mathrm{O}_{2}$ plant. The endothermic nature of the reaction makes steam-reforming of the natural gas an energy intensive process. The oxygen-ion conducting ceramic membrane technology has distinct advantages over conventional oxygen generating technologies. The process combines $\mathrm{O}_{2}$ separation from air with the partial oxidation of methane into a single reactor. Studies have indicated that such membrane reactors could be considerably smaller in size and $40 \%$ less expensive for $\mathrm{O}_{2}$ generation/ removal than the existing technologies [5-7].

Converting water and carbon dioxide into energy intensive commodities by solar powered unnatural photosynthesis has become more attractive in past few decades, by virtue of its significant part in extenuation of energy deficiency and global warming [12-17]. Syngas can be produced from splitting of $\mathrm{H}_{2} \mathrm{O}$ and $\mathrm{CO}_{2}$ by means of solar 
Citation: Riaz M, Butt MA (2018) Oxygen Transport Membranes and their Role in $\mathrm{CO}_{2}$ Capture and Syngas Production. J Membr Sci Technol 8: 181. doi:10.4172/2155-9589.1000181

thermochemical loop [18], having fast reaction kinetics and operating at higher temperature using the solar spectrum for thermal energy. A dual-step thermochemical cycle using metal oxide redox reactions [19] - where $\mathrm{O}_{2}$ is separated from $\mathrm{CO}_{2}$ or $\mathrm{H}_{2} \mathrm{O}$ and stored in oxygen-short metal oxides like ceria or perovskites during the oxidation step [20] and is subsequently discharged amidst next stage at elevated temperature, resulting into the attainment of hydrogen/ carbon monoxide and $\mathrm{O}_{2}$, in that order. Nonetheless, two-step thermochemical cycles require a very high temperature of about $1500^{\circ} \mathrm{C}$ during the endothermic step for reducing the metal oxides, necessitating solar reactors and metal oxides to be robust and durable throughout the recurring heating-cooling cycles. One likely solution to reduce the working temperature, is to eliminate the $\mathrm{O}_{2}$ produced from the equilibrium-limited breakdown of $\mathrm{CO}_{2}$ and $\mathrm{H}_{2} \mathrm{O}$ with the help of a dense OTM having mixed oxygen ion and electron conductivity [12]. A recent study into thermal breakdown of $\mathrm{CO}_{2}$ and $\mathrm{H}_{2} \mathrm{O}$ for producing syngas in OTM reactor encompassed of concurrent splitting of $\mathrm{CO}_{2}$ and $\mathrm{H}_{2} \mathrm{O}$ in a single process leading to substantial lowering of energy loss as well as equipment investment in syngas production.

On site removal of $\mathrm{O}_{2}$ produced from thermal $\mathrm{CO}_{2}$ and $\mathrm{H}_{2} \mathrm{O}$ splitting with an OTM, can overcome the thermodynamic equilibrium limit of the two breakdown reactions as depicted in Figure 5. As long as an $\mathrm{O}_{2}$ partial pressure differential exists between the feed and permeate sides, the $\mathrm{O}_{2}$ generated during co-splitting of $\mathrm{CO}_{2}$ and $\mathrm{H}_{2} \mathrm{O}$ will be continuously removed. A very small partial pressure of $\mathrm{O}_{2}$ on the permeate side can be established with the help of (i) a vacuum pumps, (ii) an inert sweep gas, or (iii) an $\mathrm{O}_{2}$ consuming reaction such as selective methane oxidation. Since splitting of both $\mathrm{CO}_{2}$ and $\mathrm{H}_{2} \mathrm{O}$ are extremely endothermic, with heat demand exceeding the heat liberated during exothermic partial oxidation of methane, the required energy can originate from the sun, using an ordinary solar oven. Thus, syngas production at an accelerated rate could be anticipated in OTM reactor even at a lower temperature of less than $1000^{\circ} \mathrm{C}$.

The $\mathrm{H}_{2} / \mathrm{CO}$ ratio in syngas is a key factor for the downstream process, and it could be attuned by altering feed gas $\mathrm{CO}_{2} / \mathrm{H}_{2} \mathrm{O}$ ratio, as depicted in Figure 6. In typical situations, the change of Gibbs' free energy $(\Delta \mathrm{G})$ for carbon dioxide splitting is greater than water. Yet, the values of $\Delta \mathrm{G}$ for mentioned reactions come closer to each other with increasing the temperature [21-23] and $\Delta \mathrm{G}$ value for $\mathrm{H}_{2} \mathrm{O}$ dissociation surpasses that of $\mathrm{CO}_{2}$ splitting at temperature of around $830^{\circ} \mathrm{C}$, which specifies that the equilibrium constant of carbon dioxide splitting is greater than that of

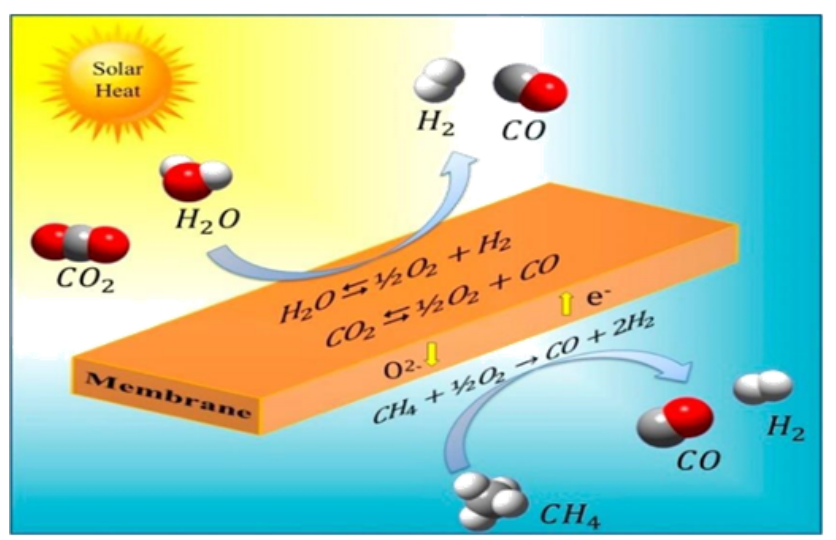

Figure 5: Simultaneous splitting of $\mathrm{H}_{2} \mathrm{O}$ and $\mathrm{CO}_{2}$ using OTM for Syngas production [21]. water splitting at elevated temperatures. Hence, to get a gas mixture of $\mathrm{H}_{2} / \mathrm{CO}$ with a ratio of two, a feed of $\mathrm{H}_{2} \mathrm{O} / \mathrm{CO}_{2}$ with a ratio of above two is required. It is worth mentioning that syngas is acquired uninterruptedly from carbon dioxide and water splitting at $930^{\circ} \mathrm{C}$ in an OTM reactor, and the working temperature is far lesser than ordinary thermochemical loop cycles.

Expeditious exclusion of $\mathrm{O}_{2}$ produced in water/ $\mathrm{CO}_{2}$ breakdown is essential in order to augment the production rate of syngas. The driving force for $\mathrm{O}_{2}$ conveyance is the pressure differential across the membrane, which can either be embedded by a very high vacuum or by using a reactive gas on the permeate side or by using a sweep gas. When methane is used as the sweep gas, it not only devours the permeated $\mathrm{O}_{2}$ but also produces supplementary syngas $\left[\mathrm{CH}_{4}+1 / 2 \mathrm{O}_{2} \rightarrow \mathrm{CO}+2 \mathrm{H}_{2}\right]$ with a $\mathrm{H}_{2} / \mathrm{CO}$ ratio of two. The incessant $\mathrm{O}_{2}$ conveyance can be upheld if permeate side $\mathrm{O}_{2}$ concentration is considerably lower than feed side.

\section{OTMs for $\mathrm{CO}_{2}$ Capture}

As per the estimates of Intergovernmental Panel on Climate Change (IPCC), Carbon Capture and Storage (CCS) potential would be somewhere between $10-55 \%$ of the total carbon extenuation effort until the year $2100 . \mathrm{CO}_{2}$ capture from power plants, particularly coal based power generation is the main focus of researchers these days. One of the most vital notions in this regard is the Integrated Gasification Combined Cycle (IGCC) for coal based power plants with $\mathrm{CO}_{2}$ capture. Substantial energy penalty associated with $\mathrm{CO}_{2}$ capture is the major snag which leads to abridged economic feasibility. Air Separation Unit (ASU), shift reactors, $\mathrm{CO}_{2}$ capture unit and gas turbine that uses fuel rich in $\mathrm{H}_{2}$ gas are the key sources of energy penalty in IGCC plants.

Typical energy consumption of modern cryogenic ASU's lies between $145-160 \mathrm{kWh} / \mathrm{t} \mathrm{O}_{2}$ [24-26]. OTMs which have the capability of separating $\mathrm{O}_{2}$ from air with a $100 \%$ selectivity - a favourable substitute to $\mathrm{O}_{2}$ production by cryogenic distillation, are likely to be used in oxyfuel and pre-combustion $\mathrm{CO}_{2}$ capture processes for gas and coal power plants [27] where partial pressure differential between the $\mathrm{O}_{2}$ rich feed side and the permeate side of the membrane is the main driving force for mass transfer. The feed stream is kept at a higher pressure than the permeate side and partial pressure of permeating $\mathrm{O}_{2}$ is kept as low as possible by either reducing the permeate $\mathrm{O}_{2}$ concentration or the permeate stream pressure. Figure 7 represents the two commonly utilized membrane operating methods.

Figure 7 (a) depicts an operating method where sweep gas is used and $\mathrm{O}_{2}$ free stream is sent to the low pressure permeate side to reduce the concentration (and thus partial pressure) of $\mathrm{O}_{2}$ on the permeate side; consequently, aggravating the driving force. The major benefit of using this method is that the feed and permeate side pressures could be set to virtually equal values, thus plummeting the pressure differential across the membrane which resultantly improves membrane's mechanical strength. Hence, the $\mathrm{O}_{2}$ generated is at a higher pressure which ultimately reduces the compression work by the gasifier. Sweep gas at a temperature close to the operating temperature of the membrane should be used. In case of excessive heat in the sweep, preheating of feed stream with the sweep gas is performed to bring its temperature down to the membrane operating temperature.

Figure 7 (b) depicts the operating method which does not involve the use of sweep gas where permeate side pressure is set at vacuum or atmospheric settings so as to curtail $\mathrm{O}_{2}$ partial pressure on permeate side [28]. This method involves no energy penalty with regards to steam extraction from the bottoming cycle for sweep gas. Nonetheless, low 
Citation: Riaz M, Butt MA (2018) Oxygen Transport Membranes and their Role in $\mathrm{CO}_{2}$ Capture and Syngas Production. J Membr Sci Technol 8: 181. doi:10.4172/2155-9589.1000181

Page 5 of 8

pressure of produced $\mathrm{O}_{2}$ leads to an energy penalty in the shape of compression of $\mathrm{O}_{2}$ to the gasifier conditions. Hefty pressure differential between the permeate and feed side is yet another drawback of this method necessitating fabrication of such a membrane in which mechanical failure could be avoided by meeting certain prerequisite. Preliminary scrutiny of the stated methods demonstrates that the one without a sweep gas yields promising cycle efficiency.

Figure 8 shows a two stage combustor with the OTM placed
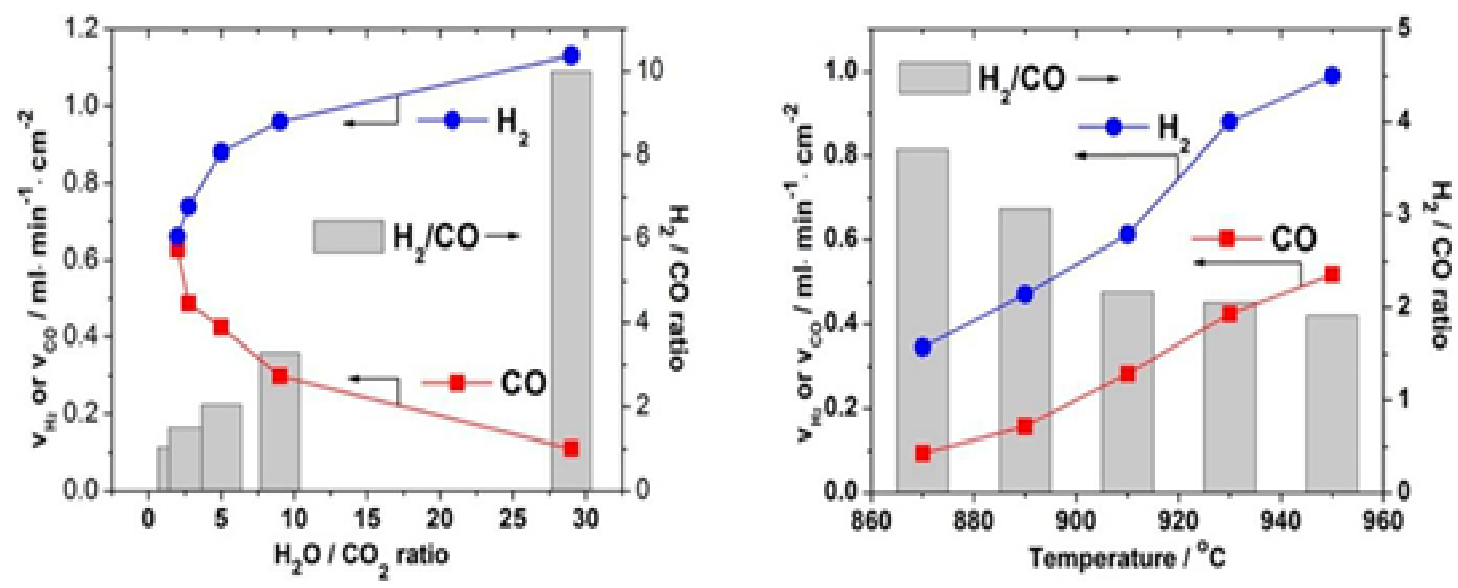

Figure 6: Thermal co-splitting of water and $\mathrm{CO}_{2}$ as a function of temperature and $\mathrm{H}_{2} \mathrm{O} / \mathrm{CO}_{2}$ ratio [21].

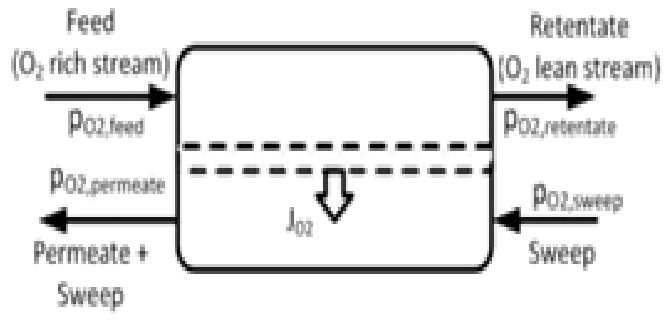

(a)

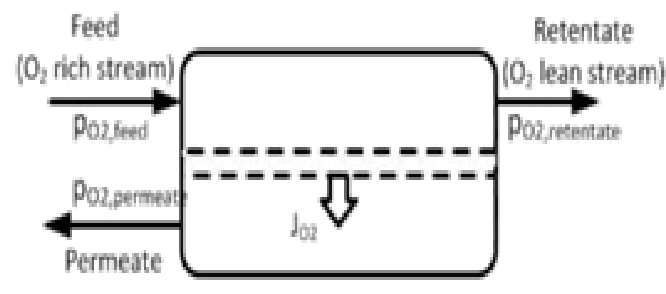

(b)

Figure 7: Operating methods of the membrane (a) with sweep gas; (b) without sweep gas.

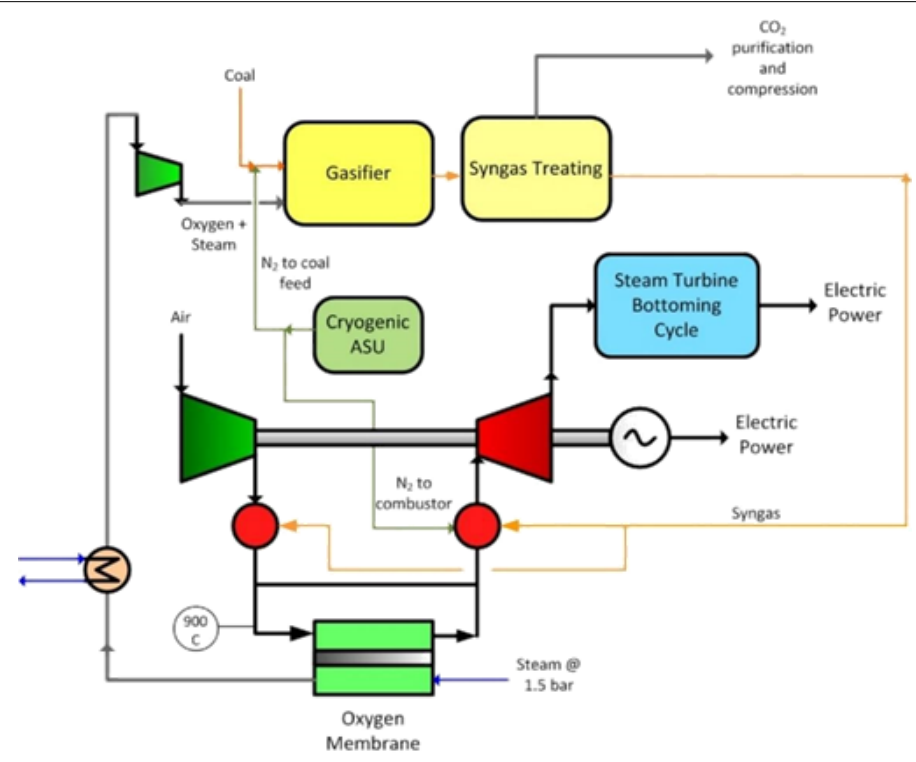

Figure 8: IGCC plant integrated with OTM and $\mathrm{CO}_{2}$ capture. 
Citation: Riaz M, Butt MA (2018) Oxygen Transport Membranes and their Role in $\mathrm{CO}_{2}$ Capture and Syngas Production. J Membr Sci Technol 8: 181. doi:10.4172/2155-9589.1000181

Page 6 of 8

between the two stages used to augment the process efficiency with $100 \%$ air integration. With respect of $\mathrm{O}_{2}$ production requirement, only part of the air enters the OTM from the compressor exhaust. The overall plant performance shows overall plant efficiency of $37.3 \%$ with a $\mathrm{CO}_{2}$ capture rate of $90.9 \%$. This is because (i) preheating of OTM feed to $900^{\circ} \mathrm{C}$ does not require any extra fuel, and (ii) efficiency is not affected by the degree of air separation. A small capacity cryogenic ASU is also required for this process, which along with the GT hampers the flexibility and operability of the process.

\section{Critical issues in OTMs and the way forward}

Aside from substantial developments in the past decades, numerous concerns are yet to be addressed in the area of mixed conducting ceramic membranes. Significant concerns associated with high temperature $\mathrm{O}_{2}$ separation from air using ceramic-based inorganic membranes for are highlighted in Figure 9. By altering various factors like membrane thickness, material, microstructure and membrane operating temperature, the $\mathrm{O}_{2}$ permeation fluxes could be significantly enhanced. Membrane stability in mixed conducting ceramic membranes is one of the major issues because most membrane materials having immense ionic conductivity have poor chemical and/or mechanical stability and vice versa. Most ceramic membranes of perovskite-type are usually constructed from alkaline earth material having high $\mathrm{O}_{2}$ permeation flux properties but on the same time having long-lasting problems with stability, because of their affinity for reactions with gas species such as sulfur dioxide, carbon dioxide or vapors of water [13].

Since $\mathrm{O}_{2}$ permeation flux has an inverse relation with the membrane thickness, present focus of the manufacturers is on making tens of micrometers thick membranes. Common membrane designs comprise of asymmetric structures where thin, nonporous membranes are supported on a porous substrate providing the desired mechanical strength to the membrane. The porous substrate may be constructed from the same material as of membrane and apparently asymmetric membranes with thin nonporous layer and a porous support (Figure 10) could defeat these problems [14]. In most of the cases, porous support having a pore size lesser than skin layer thickness is preferred instead of the one having adequate mechanical strength. The support layer must have a chemical and thermal expansion similar to those of the skin layer and it must endure the membrane working temperature for a prolonged period of time without undergoing any structural or

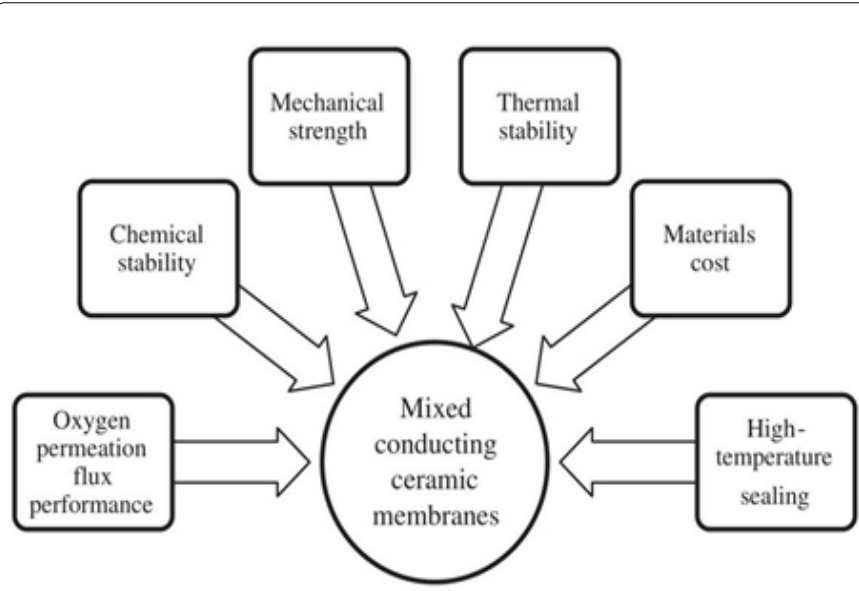

Figure 9: Critical issues associated with mixed conducting ceramic membranes [36].

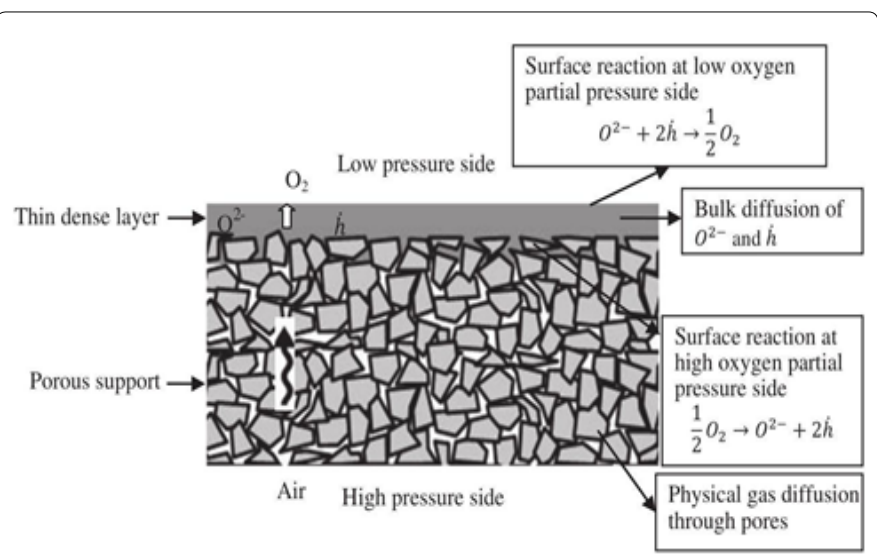

Figure 10: An asymmetric-structured membrane.

chemical changes. $\alpha-\mathrm{Al}_{2} \mathrm{O}_{3}$ is the widely chosen support material due to its low price, ample supply, and its effortless processing into consistent and extremely porous substrates however, it has poor expansion coefficient in comparison to most of $\mathrm{O}_{2}$ permeable mixed-conducting perovskites which dictates its impracticality to be used as a support material.

Membrane surface alterations with an advanced surface exchange rate layer appears to be a rather attractive alternative due of its positive influence on surface kinetic reaction rate, thereby augmenting the $\mathrm{O}_{2}$ permeation flux. Application of catalytic materials (e.g., Argentum) on membrane surface also increases the surface exchange reaction rate, thereby improving the $\mathrm{O}_{2}$ permeation flux.

Meeting the requirements desired mechanical strength and stability of the membrane along with an appreciable $\mathrm{O}_{2}$ permeation flux in single-phase membrane material is rather a difficult task. That is where the composite materials comprising of a dual-phase prepared from $\mathrm{O}_{2}$ ionic and electronic conducting phases in the form of mixed conducting membrane materials come into play. Creation of a dual-phase MIEC membrane (Figure 11) with the dispersion of insoluble metallic or another ceramic phase having admirable electron conducting properties into copiously ionic conducting phase is an alluring preference vis-àvis $\mathrm{O}_{2}$ separation is concerned. Aside from optimistic future prospects, further assessments of various amalgamations of materials other than metals are required to enhance the performance dual phase membranes as perovskite metal membranes are susceptible to defect formation which could compromise the purity of obtainable $\mathrm{O}_{2}$.

When compared to seasoned cryogenic air separation, separation based on ceramic membranes is quite a new technology as far as the production of $\mathrm{O}_{2}$ from air is concerned for applications such as power generation and fuel production through the processes like oxy-fuel combustion, coal gasification and syngas production. Conspicuously, membrane materials are the core of membrane-based separation at high temperatures and they should be fully stable, robust, and skulk resistant having extraordinary $\mathrm{O}_{2}$ flux properties. Consequently, improvements are anticipated in membrane performance for oxidizing and reducing environments necessitating development of rational projects under realworld operating conditions so as to obtain incredible $\mathrm{O}_{2}$ production capacities for industrial consumption.

Membrane surface area has been under constant scrutiny because it increases with decrease in $\mathrm{O}_{2}$ differential partial pressure; thus increasing the recovery rate of $\mathrm{O}_{2}$. Numerous abstract preferences 
Citation: Riaz M, Butt MA (2018) Oxygen Transport Membranes and their Role in $\mathrm{CO}_{2}$ Capture and Syngas Production. J Membr Sci Technol 8: 181 doi:10.4172/2155-9589.1000181

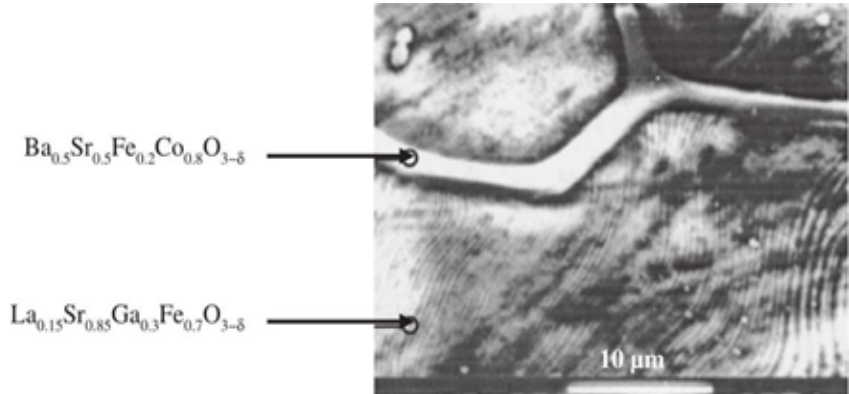

Figure 11: SEM of a new BSCF-LSGF dual-phase membrane [38].

including hollow fiber membranes [15], monolithic tubes [29-33], planar arrangements [34] and honeycomb structures [33-38] are available to fulfil the obligatory rudiments.

\section{Conclusions}

The commercial opportunities offered by ceramic membrane technologies are substantial. No single material or technology will fulfill such a diverse range of applications. The commercialization of these membranes has a bright future with regards to improved $\mathrm{O}_{2}$ separation from air. The amalgamation of an OTM reactor with catalytic thermolysis and solar energy offers a ground-breaking itinerary for transforming water and $\mathrm{CO}_{2}$ into syngas. An efficiency improvement of $0.7 \%$ with OTM integrated IGCC plant has some eloquence over the reference IGCC plant with cryogenic ASU with regards to future prospects. Other extremely significant issues like membrane module, geometry, and sealing must be addressed in order to enhance the performance of these membranes

Far-reaching research and development efforts are still required for commercial availability of MIEC membranes. Promising potential of ceramic-based membrane technology especially in the areas of fuel production, cleaner environment and sustainable energy delivery, anticipate their widespread future usage for separation of $\mathrm{O}_{2}$ from air.

\section{References}

1. Burggraaf AJ, Cot L (1996) Fundamentals of Inorganic Membrane Science and Technology. Elsevier Science Vol. 4.

2. Ermsley J (2011) Nature's Building Blocks: An A-Z Guide to the Elements. Oxford University Press.

3. He Y, Zhu X, Li Q, Yang W (2009) Perovskite oxide absorbents for oxygen separation. AIChE Journal 55: 3125-3133.

4. Bose AC (Ed.) (2001) Inorganic Membranes for Energy and Environmental Applications. Springer.

5. Balachandran U, Dusek JT, Sweeney SM, Poeppel RB, Mieville RL, et al. (1995) Methane to syngas via ceramic membranes. American Ceramic Society Bulletin 74: 71 .

6. Mazanec TJ (1996) High temperature electroceramic oxygen separation and reaction. The Electrochemical Society Interface 5: 46-49.

7. Dyer PN, Richards RE, Russek SL, Taylor DM (2000) lon transport membrane technology for oxygen separation and syngas production. Solid State Ionics 134: 21-33.

8. Badwal SPS, Ciacchi FT (2000) Oxygen-ion conducting electrolyte materials for solid oxide fuel cells. Ionics 6: 1-21.

9. Kim S, Yang YL, Christoffersen R, Jacobson AJ (1998) Determination of oxygen permeation kinetics in a ceramic membrane based on the composition SrFeCo0.5O3.25-ס. Solid State Ionics 109: 187-196.
10. Kharton VV, Yaremchenkop AA, Kovalevsky AV, Viskup AP, Naumovich EN et al. (1999) Perovskite-type oxides for high-temperature oxygen separation membranes. Journal of Membrane Science 163: 307-317.

11. Aasland S, Tangen IL, Wiik K, Ødegård R (2000) Oxygen permeation of SrFe0.67Co0.33O3-ס. Solid State lonics 135: 713-717.

12. Sunarso J, Baumann S, Serra JM, Meulenberg WA, Liu S, et al. (2008) Mixed ionic-electronic conducting (MIEC) ceramic-based membranes for oxygen separation. Journal of Membrane Science 320: 13-41.

13. Thursfield A, Metcalfe IS (2004) The use of dense mixed ionic and electronic conducting membranes for chemical production. J Mater Chem 14: 2475-2485.

14. Yin X, Hong L, Liu ZL (2007) Asymmetric tubular oxygen-permeable ceramic membrane reactor for partial oxidation of methane. J Phys Chem C 111: 9194 9202.

15. Schiestel T, Kilgus M, Peter S, Caspary KJ, Wang H, et al. (2005) Hollow fibre perovskite membranes for oxygen separation. Journal of Membrane Science 258: $1-4$.

16. Li C, Hu T, Zhang H, Chen Y, Jin J, et al. (2003) Preparation and characterization of supported dense oxygen permeating membrane of mixed conductor $\mathrm{La} 2 \mathrm{NiO} 4+\delta$. Journal of Membrane Science 226: 1-7.

17. Armaroli N, Balzani V (2007) The Future of Energy Supply: Challenges and Opportunities. Angew Chem Int Ed Engl 46: 52-66.

18. Steinfeld A (2005) Solar thermochemical production of hydrogen - A review. Solar Energy 78: 603-615.

19. Roeb M, Neises M, Säck JP, Rietbrock R, Monnerie N, et al. (2009) Operational strategy of a two-step thermochemical process for solar hydrogen production. International Journal of Hydrogen Energy 34: 4537-4545.

20. Bulfin B, Call F, Lange M, Lübben O, Sattler C, et al. (2015) Thermodynamics of $\mathrm{CeO} 2$ thermochemical fuel production. Energy Fuels 29: 1001-1009.

21. Liang W, Cao Z, He G, Caro J, Jiang H (2017) Oxygen transport membrane for thermochemical conversion of water and carbon dioxide into synthesis gas. ACS Sustainable Chem Eng 5: 8657-8662.

22. Luo H, Jiang H, Klande T, Cao Z, Liang F, et al. (2012) Novel cobalt-free, noble metal-free oxygen-permeable 40Pr0.6Sr0.4FeO3- $\delta-60 \mathrm{Ce} 0.9 \mathrm{Pr} 0.102-\delta$ dualphase membrane. Chem Mater 24: 2148-2154.

23. Graves C, Ebbesen SD, Mogensen M, Lackner KS (2011) Sustainable hydrocarbon fuels by recycling $\mathrm{CO} 2$ and $\mathrm{H} 2 \mathrm{O}$ with renewable or nuclear energy. Renewable Sustainable Energy Reviews 15: 1-23.

24. Chen D, Chen C, Baiyee Z, Shao Z, Ciucci F (2015) Nonstoichiometric oxides as low-cost and highly-efficient oxygen reduction/evolution catalysts for lowtemperature electrochemical devices. Chem Rev 115: 9869-9921.

25. Beysel G (2009) Enhanced cryogenic air separation - a proven process applied to oxyfuel. $1^{\text {st }}$ International Oxyfuel Combustion Conference, Cottbus.

26. Trainer JP, Dubettier R, Perrin N (2009) Air separation unit for oxy-coa combustion systems. $1^{\text {st }}$ International Oxyfuel Combustion Conference, Cottbus.

27. Bredesen R, Jordal K, Bolland O (2004) High temperature membranes in powe generation with $\mathrm{CO} 2$ capture using OMCM technology. Chemical Engineering \& Processing 43: 1129-1158.

28. Air Products and Chemicals, Inc. (2006) Ion transport membrane module and vessel system with directed internal gas flow. Patent EP1676811A2.

29. Tan X, Liu YT, Li K (2005) Mixed conducting ceramic hollow-fiber membranes for air separation. AIChE Journal 51: 1991-2000.

30. Kim S, Yang YL, Jacobson AJ, Abeles B (1998) Diffusion and surface exchange coefficients in mixed ionic electronic conducting oxides from the pressure dependence of oxygen permeation. Solid State Ionics 106: 189-195.

31. Lin YS, Wang Y, Han J (1994) Oxygen permeation through thin mixed-conducting solid oxide membranes. AIChE Journal 40: 786-798.

32. Pfaff EM, Zwick M (2009) Oxyfuel combustion using perovskite membranes Ceramic Engineering and Science Proceedings 28: 23-31.

33. Bruun T, Werswick B (2007) Method and equipment for distribution of two fluids into and out of the channels in a multi-channel monolithic structure and use thereof. Patent EP1627198B1. 
Citation: Riaz M, Butt MA (2018) Oxygen Transport Membranes and their Role in $\mathrm{CO}_{2}$ Capture and Syngas Production. J Membr Sci Technol 8: 181. doi:10.4172/2155-9589.1000181

Page 8 of 8

34. Armstrong P, Underwood R, Stein V, Foster T (2008) ITM oxygen for the real world: pilot scale testing and beyond. International Pittsburgh Coal Conference, Pittsburgh, PA, USA.

35. Bhalla AS, Guo R, Roy R (2000) The perovskite structure - a review of its role in ceramic science and technology. Mat Res Innovat 4: 3-26.

36. Hashim SM, Mohamed AR, Bhatia S (2010) Current status of ceramic-based membranes for oxygen separation from air. Advances in Colloid and Interface Science 160: 88-100.

37. Ikeguchi M, Ishii K, Sekine Y, Kikuchi E, Matsusaka M (2005) Improving oxygen permeability in SrFeCo0.5Ox asymmetric membranes by modifying supportlayer porous structure. Mater Letters 59: 1356-1360.

38. Wang H, Yang WS, Cong Y, Zhu XF, Lin YS (2003) Structure and oxygen permeability of a dual-phase membrane. Journal of Membrane Science 224: 107-115. 